\title{
Quantification and Aging of the Post-Blast Residue of TNT Landmines
}

Jimmie C. Oxley, Ph.D.; James L. Smith, Ph.D.; Elmo Resende, Ph.D.; Evan Pearce, B.Sc. Department of Chemistry

University of Rhode Island

Kingston, RI 02882

USA 


\begin{abstract}
Post-blast residues are potential interferents to chemical detection of landmines. To
\end{abstract} assess the potential problem related to 2,4,6-trinitrotoluene (TNT), its post-blast residue was identified and quantified. In the first part of this study laboratory-scale samples of TNT (2 g) were detonated in a small-scale explosivity device (SSED) to evaluate the explosive power and collect post-blast residue for chemical analysis. Initiator size was large relative to the TNT charge; thus, issues arose regarding choice of initiator, residue from the initiator and afterburning of TNT. The second part of this study detonated $75 \mathrm{~g}$ to $150 \mathrm{~g}$ of military-grade TNT (typical of antipersonnel mines) in 55 gallon barrels containing various witness materials (metal plates, sand, barrel walls, the atmosphere). The witness materials were analyzed for explosive residue. In a third set of tests, $75 \mathrm{~g}$ samples of TNT were detonated over soil [from Fort Leonard Wood or Sandia National Laboratory] in an indoor firing chamber (100 m x $4.6 \mathrm{~m}$ x 2.7m high). Targeted in these studies were TNT and four explosive related compounds (ERC): 2,4-dintrotoluene (DNT), 1,3-dinitrobenzene (DNB), 2- and 4-aminodinitrotoluene (2ADNT and 4-ADNT). The latter two are microbial degradation products of TNT. Post-blast residue was allowed to age in the soils as a function of moisture contents $(5 \%$ and $10 \%)$ in order to quantify the rate of degradation of the principal residues [TNT, DNT, and DNB] and formation of the TNT microbial degradation products [2ADNT and 4-ADNT]. The major distinction between landmine leakage and post-blast residue was not the identity of the species but relative ratios of amounts. In landmine leakage the DNT/TNT ratio was usually greater than one. In post-blast residue it was on the order of one to one hundredth of a percent, and the total amount of pre-blast residue (landmine leakage) was a factor of $1 / 100$ to $1 / 1000$ less than post-blast. In addition, landmine leakage resulted in low DNT/ADNT ratios, usually less than one, whereas pre-blast residues 
started with ratios above 20. Because with time DNT decreased and ADNT increased, over a month the ratio decreased by a factor of 2 . The rate of TNT degradation in soil observed in this study was much slower than that reported when initial concentrations of TNT were lower. Degradation rates yielded half-lives of 40 and 100 days for 2,4-DNT and TNT, respectively.

KEYWORDS: forensic science, landmines, TNT, decomposition, soil, detection 
Annually, landmines kill or maim more than 15,000 people; most victims are civilians. ${ }^{1-3}$ Since World War II more than 400 million landmines have been placed, at least 65 million since 1978. ${ }^{1}$ The U.S. Department of State estimates that between 65 and 110 million un-cleared landmines are currently in the soil of 62 nations; others estimate the number as high as 200 million. A 1995 report states that even with a 30 person de-mining team, only an average of 2300 $\mathrm{m}^{2}$ could be cleared per day at a cost per landmine of $\$ 200$ to $\$ 1000 .^{3}$ This figure is in sharp contrast with the average price of a mine--between $\$ 3$ and $\$ 15$. The low cost, ease of use, and effectiveness make eradication of landmines a difficult task. The explosive 2,4,6-trinitrotoluene (TNT) is the main charge in the majority of landmines, but RDX, Tetryl, and PETN are also used. ${ }^{4}$ The main charge in mines range in size from tiny anti-personal mines, 30 to $700 \mathrm{~g}$ (Fig. 1), to the anti-tank mines, 1 to 10 kilograms. The housing for mines varies from wooden boxes to metal or plastic shells which provide varying degrees of leak resistance. Various options exist for triggering mines, and the presence of a booster appears to be optional. Table 1 was prepared after review of the almost 700 landmines featured in reference 4 . Only about ten percent provided sufficient data for this Table: explosive fill; average charge size, container; and the average charge-to-initiator ratio.

Even with myriad new technological developments, dogs remain one of the most reliedon landmine detectors world-wide. Dogs are believed to directly "smell" the explosive and, thus, avoid false positives. Several concerns arise in contemplating design of instrumentation which locates mines by chemical sensing: the amount of explosive signature available from the mine, the presence of interfering explosive related compounds (ERC) resulting from previous military activity (i.e. post-blast residue) and the persistence of ERC (i.e. the rate of decay). This study addressed the magnitude of the initial ERC deposits and the decay rate. 
The main charge in most landmines is 2,4,6-trinitrotoluene (TNT). ${ }^{4}$ However, when "leakage" from landmines was examined at a test landmine field located at Fort Leonard Wood, MO, TNT was not the predominant signature. ${ }^{5,6}$ In many cases, explosive related compounds (ERC) were found, instead of TNT. 2,4-Dintrotoluene (DNT) and 1,3-dinitrobenzene (DNB) are found in manufactured TNT. Both 2- and 4-aminodinitrotoluene (2ADNT and 4-ADNT) are degradation products of TNT, formed by microbial action in the soil. 2,4-DNT and DNB also undergo degradation to form amino-nitro-toluene (ANT) and nitro-aniline, respectively, but these are difficult to detect because of the lower initial concentrations of the precursor. ${ }^{5,6}$ The results in Table 2 represent the ERC signatures for landmines buried for about 8 months.

The objective of this study was to identify and quantify post-blast residue of TNT and determine the rate of degradation in two soil types. Several test set-ups were employed in an effort to contain and quantify residue. In a companion study, Cold Region Research and Engineering Laboratory (CRREL) and Sandia National Laboratory (SNL) functioned landmines in open fields and collected what necessarily was a minute fraction of the residue. ${ }^{5,6}$ Our strategy was to attempt to quantify the residue. The first experiments were performed on 2-g samples of TNT, RDX, and Tetryl using a small-scale explosivity device (SSED). ${ }^{7-11}$ The second collection of experiments detonated 75-g or 150-g of TNT in 55 gallon barrels. Various witness materials were used in the barrel tests - the barrel walls, clean sand, aluminum witness plates. Finally, 75 $\mathrm{g}$ of TNT was detonated in an indoor firing chamber over soil. Two soils--one loamy (Fort Leonard Wood) and one sandy (Sandia National Laboratory)--were used. After the detonation, moisture content of the soils was adjusted to $5 \%$ or $10 \%$, and the degradation of the principal post-blast residues (TNT, 2,4-DNT, 2-ADNT, 4-ADNT, 1,3-DNB) was tracked at room temperature over several months. 


\section{Experimental Section}

Two-gram Tests

The detonation chamber was a heavy-walled, bolted-closure, stainless-steel vessel with interior dimensions (3" x 9") giving about one liter volume; its lid was held on with eight bolts. The energetic material ( $2 \mathrm{~g}$ ) was packed in a tapered 0.303 " brass cartridge, with the base thicker than the open end..$^{7-11}$ Since the object of these tests was to examine residue from the detonation, it was necessary to first examine the residue produced by the initiating device. Three different initiators were examined: Star \# 8 detonators and exploding bridge wire detonators RP-3 and RP-2 from Reynolds Initiation Systems, Inc. After reviewing the results, the smallest detonator (RP3) was used in the residue analysis tests. Table 3 shows the composition of the detonators and their observed post-blast residue. Although the detonation chamber was vented, sufficient post-blast vapor remained to allow sampling with a Solid Phase Micro-Extraction Fiber (SPME) within a minute after the detonation. A polydimethyl-siloxane (PDMS) SPME was exposed to the chamber atmosphere for one minute and then desorbed onto a Hewlett Packard (HP) Model 5890 Gas Chromatograph/HP model 5971 with mass selective detector (GC/MS). A GC Chrompack PoraPLOT Q capillary column $(25 \mathrm{~m} \mathrm{x} 0.25 \mathrm{~mm})$ was used for separations. ${ }^{12}$ The condensed blast residue was extracted from the cylinder walls with acetonitrile $(50 \mathrm{~mL})$. The solvent was filtered through a Gelman $0.2 \mathrm{:m}$ nylon Acrodisc 13 syringe filter and concentrated to 1 to $2 \mathrm{~mL}$ with a stream of nitrogen gas. Three instruments were used for chemical analysis of condensed blast residue: a HP Model 5890 gas chromatograph (GC) equipped with a J\&W DB-5 capillary column (30m x 0.32mm) and electron capture detector (ECD); a HP Model 1100 high pressure liquid chromatograph (HPLC) with diode array detector; and a HP model 5890 GC with HP model 5971 mass selective detector (GC/MS). Chromatograph conditions are given in Table 4. 


\section{Barrel Tests with Aluminum Witness Plates}

The 55-gallon barrel tests used amounts of explosive comparable to that found in antipersonnel landmines. A preliminary test using a 150-g charge of TNT dramatically split the barrel. Furthermore, extensive efforts to clean the barrel walls prior to blast failed to remove contaminants which significantly interfered with residue analysis. These difficulties were overcome by reducing the TNT charge to 75 grams and lining the barrel with a double layer of aluminum foil on top of which thirty-two, flame-cleaned aluminum witness plates $(10.2 \mathrm{~cm} \mathrm{x}$ $10.2 \mathrm{~cm})$ were affixed. The plates were evenly distributed in three rows of eight $(17 \mathrm{~cm}, 42 \mathrm{~cm}$, and $70 \mathrm{~cm}$ from the top of the $86 \mathrm{~cm}$ high barrel); four witness plates were attached to the bottom and the lid of the barrel. The witness plates covered about $16 \%$ of the barrel walls. In most cases, SPME fibers were held over the open barrel (lids were blown off) for two minutes immediately (within 5 minute) after the blast. Then each witness plate was wrapped in aluminum foil and heat-sealed in polyethylene bags for transport to the lab. The retrieved witness plates were individually soaked in acetonitrile $(100 \mathrm{~mL})$ for 48 hours; soot was manually scraped from each plate. The acetonitrile was concentrated to $2 \mathrm{~mL}$ under a stream of nitrogen gas. The concentrated solution was filtered (0.2 : m PTFE Acrodisc syringe filters) into Agilent amber, wide-mouth, crimp-top $2 \mathrm{~mL}$ vials and stored at $-20^{\circ} \mathrm{C}$ awaiting GC/ECD analysis. The ERC's (TNT, 1,3-DNB; 2,6-DNT; 2,4-DNT; 2-A-DNT; and 4-A-DNT) were identified by retention time and quantified using two different chromatographic columns (Restec RTx-225 and J\&W DB-5MS) for confirmation.

Firing Chamber Tests

This test was devised to purposely contaminate soil with residue from TNT detonations. Soil from Ft. Leonard Wood (FLW) and Sandia National Laboratory (SNL) was sieved (\#2 sieve) 
and dried on a glass plate in an oven at $60^{\circ} \mathrm{C}$ for one hour. After drying, the soil was stored in a one gallon paint can which had been cleaned with methanol, acetonitrile, and acetone. Two indoor detonations of 75g of TNT were performed in a well-ventilated room approximately 100 $\mathrm{m}$ long, $4.6 \mathrm{~m}$ wide, and $2.7 \mathrm{~m}$ high ( $328 \mathrm{ft} \times 180$ " x 96"). About 3 pounds of the witness soil was sprinkled over two $(63.5 \mathrm{~cm} \times 119 \mathrm{~cm})$ aluminum trays double-wrapped with aluminum-foil and placed side by side to give a total surface of $127 \mathrm{~cm} \mathrm{x} 119 \mathrm{~cm}$. For each detonation a different soil was used (FLW or SNL). No attempt was made to completely cover the trays with soil. Around the trays, the floor was covered with a double layer of aluminum foil, out to about $2.54 \mathrm{~m}$. The military-grade TNT $(\sim 75 \mathrm{~g})$, suspended $\sim 60 \mathrm{~cm}$ above the center of the trays, was detonated using a number 12 detonator. Following the detonation, the soil was poured into a stainless-steel bowl that had been previously rinsed with tap water, distilled water, acetone and acetonitrile. The soil was mixed for 20 minutes using an aluminum-wrapped wooden spoon. The soil was then weighed and sealed in doubled plastic bags. The bagged samples were transported in an insulated chest containing dry ice to the laboratory where they were stored in the laboratory freezer $\left(-20^{\circ} \mathrm{C}\right)$. Time from detonation to packing in dry ice was approximately one hour. In the laboratory the soils (FLW and SNL) were removed from the freezer, tumbled for 8 hours, at $-5^{\circ} \mathrm{C}$ to assure homogeneous distribution of explosive residue. After the mixing, five samples (5 g each) were extracted with acetonitrile and analyzed for homogeneity of the ERC's. The results showed satisfactory homogeneity about $80 \mathrm{mg}$ of TNT in each soil type with standard deviation less than $1 \%$. Ninty-six samples (5g each) of each soil were weighed into snap-top plastic vials. To half of them $0.25 \mathrm{~mL}$ of water containing $60 \mathrm{mg}$ of RDX/L $(0.015 \mathrm{mg} \mathrm{RDX} / 5 \mathrm{~g}$ soil) were added; to the other samples $0.25 \mathrm{~mL}$ of water and $0.25 \mathrm{~mL}$ of the RDX spiked water were added. The RDX was used as a internal standard for the chromatographic analyses. 
Samples were allowed to equilibrate at room temperature in a covered, insulated box. The sampling schedule was more frequent early in the aging cycle. At recorded time intervals, $5 \mathrm{~g}$ soil samples were extracted with $5 \mathrm{~mL}$ of acetonitrile, followed by sonication (12 hours) at $10^{\circ} \mathrm{C} . .^{13,14}$ The acetonitrile extract was filtered twice using syringe filters $(1.0 \mu \mathrm{m}$ then $0.20 \mu \mathrm{m}$ Acrodisc PTFE filters); the extract was stored in Agilent amber, wide-mouth, crimp-top $2 \mathrm{~mL}$ vials, in a freezer $\left(-20^{\circ} \mathrm{C}\right)$ until analysis. Quantification of most ERC's was accomplished using a HP5890 GC/ECD. The acetonitrile extracts $(1 \mu \mathrm{L})$ were directly injected $\left(250^{\circ} \mathrm{C}\right)$ into a split/splitless port equipped with a deactivated Supelco glass inlet liner and a DB-5MS fusedsilica column (6m x $0.53 \mathrm{~mm}$ ID) with $1.5 \mu \mathrm{m}$ film thickness of 5\%-(phenyl)-95\%-dimethyl polysiloxane (J\&WScientific). Since the concentrations of TNT were above the linear range $(\sim 200 \mu \mathrm{g} / \mathrm{L})$ of the ECD detector, the acetonitrile extracts were re-analyzed using a reverse-phase high performance liquid chromatography using a HP Model 1100 system with photodiode array detector. ${ }^{13,14}$ Samples $(1 \mu \mathrm{L})$ were introduced via autosampler. Conditions, retention times and detection limits are shown in Table 4.

\section{Results and Discussion}

\section{Two-gram Detonation Tests}

Three initiators (Star \#8, RP-3 EBW and RP2-EBW) were used for 2-g charges of explosive in the SSED. When the detonators were functioned without an explosive charge, PETN (and RDX in the case of RP-2) was observed remaining from the detonator. When the detonators functioned against a charge, it was notable that the charge was not generally observed when the large detonator (Star \# 8) was employed. The presence of TNT and Tetryl residue was confirmed when the EBW initiators were used, but RDX was only tentatively, not conclusively, identified. Other species were 
observed; Table 3 reports those species identified by GC/MS using a spectral library of reliability $90 \%$ or better. Most of these products were attributed to the initiator. Various phthalates probably were produced by the wire insulation of the detonator, while the condensed-ring products could also come from the insulation or from soot of the explosives. As a result of this preliminary investigation, the smallest initiators (RP-3 EBW) were used for the majority of chemical analysis tests. In each of these tests unconsumed explosive (TNT, RDX, or Tetryl) was extracted from the cylinder walls. However, neither SPME fibers nor acetonitrile extracts of the cylinder walls showed the targeted ERC's. Only in the TNT blast was benzonitrile observed among both the condensed-phase and the SPME products. The 2-g detonation could be conveniently conducted in our laboratory; however, there was concern that post-blast residue from a confined 2-g blast might not be representative of larger detonations. TNT is an oxygen-deficient explosive and a small container could restrict after-burning of the TNT that would occur in free-field detonation. To determine whether after-burn was significant in the SSED, the 2-g tests, normally performed under air, were performed under oxygen and under nitrogen (Table 5). In both cases, the flaked TNT performed poorly in the explosivity test. About $89 \%$ of the 0.303 brass cartridge remained attached to the base after detonation of the flaked TNT as compared to $30 \%$ using powdered military grade TNT (Table 5) However, the purpose of these tests was to analyze for the amount TNT remaining under nitrogen versus under oxygen. There was a factor of 10 less TNT remaining when the TNT was initiated under oxygen instead of nitrogen (Table 5). This suggested that after-burning was an important consideration at the 2-g scale, at least with an oxygen-deficient explosive like TNT. It was concluded that the restricted volume of the SSED affected the amount of explosive residue remaining but not the performance of the explosive. 
Barrel Tests with Witness Plates

The 32 witness plates from each 55-gallon barrel test were analyzed individually using GC/ECD. TNT, 1,3-DNB; 2,6-DNT; 2,4-DNT; 2-A-DNT; and 4-A-DNT were identified and quantified using two different chromatographic columns (RTx-225 and DB-5MS). Not surprisingly, the witness plate results show that TNT and the ERC's were distributed symmetrically in a pattern such that they were most concentrated lateral to the location of the suspended TNT charge (Table 6). Results were relatively reproducible. On average, 16 mg TNT was recovered from each plate. Extrapolating to the 32 plates covering $15.6 \%$ of the barrel suggested that approximately $4.5 \%$ of the TNT survived the detonation. The amounts of ERC's observed were significantly less than the TNT (Table 7). In each test 2,4-DNT was the most prominent ERC. Preliminary studies showed that our GC/MS analysis of SPME fibers did not have sufficient sensitivity to detect TNT nor the ERC's; thus GC/ECD (DB-5MS column) was used. The disadvantage of this method, of course, was that only targeted compounds could be conclusively identified. However, with this increased sensitivity, TNT, DNB, and DNT were observed on the SPME fibers. For five experiments, air samples were taken using three different SPME fibers--PDMS/divinylbenzene, polyacrylate, and carboxen/PDMS - the latter giving slightly lower readings, but no conclusion should be drawn from that one result. Table 8 reports the average found in the five trials, reported in terms of micrograms (ug) of ERC's thermolyzed from the fibers. Regardless of the witness material - plate or air (sampling vapor)--the amounts of ERC's observed were significantly less than the TNT and their amounts relative to TNT were approximately the same. In each test 2,4-DNT was the most prominent (Table 8). 
Firing Chamber Tests

The soil containing the post-blast residue [TNT and the ERC's (2,4-DNT, 1,3-DNB, 2ADNT, and 4-ADNT)] was shipped to the laboratory where it was moistened and allowed to equilibrate in the dark at room temperature. For each soil, five "day zero" samples were analyzed to assess homogeneity; it appeared to be satisfactory (Table 9). Analysis of the soil at time zero indicated about $80 \mathrm{mg}$ of TNT in $5 \mathrm{~g}$ of the witness soil $(77 \mathrm{mg} / 5 \mathrm{~g}$ FLW and $84 \mathrm{mg} / 5 \mathrm{~g} \mathrm{SNL})$ immediately following detonation. This value was higher than expected; therefore, the test was re-run in our laboratory with the same result and in the CRREL laboratory where they confirmed our high estimates of TNT [87.5mg/5gsoil (SNL) and $105 \mathrm{mg} / 5 \mathrm{~g}$ soil (FLW)]. If the soil were thoroughly homogenized, this quantity represented $\sim 22 \mathrm{~g}$ of TNT spread over the 3 pounds of soil used as witness material.

$$
0.080 \mathrm{~g} \text { TNT/ } 5 \mathrm{~g} \text { soil } *[3 \mathrm{lb} \text { soil } * 454 \mathrm{~g} / \mathrm{lb}]=22 \mathrm{~g} \text { TNT }
$$

Since only $75 \mathrm{~g}$ of TNT was initiated, $22 \mathrm{~g}$ indicated the detonation was significantly incomplete ( $\sim 30 \%$ remaining in the soil). This amount of un-detonated TNT is extremely high and would represent a poorly functioning device. The TNT blocks used in the firing chamber tests and in the witness-plate-in-barrel tests were from a lot of military-grade TNT provided by Sandia National Laboratory; they were quite brittle. One block was analyzed for ERC's. The results are shown in Table 10 along with the relative ratios of the ERC's to the TNT. The amounts and ratios are almost identical to those found after detonation over soil in the firing chamber tests, but about an order of magnitude lower from those found on the witness plate tests and much lower than those Jenkins found when a PMA2 was detonated over snow. ${ }^{16}$ We believe the increase in TNT/ERC ratios in the latter two tests is related to the decrease in un-detonated TNT--30\% in the soil in the 
firing chamber versus $2-4 \%$ on the plate in the barrel versus $\sim 0.008 \%$ from the PMA2 (100 g TNT with 13g RDX booster) in snow. If TNT detonates while the ERC's do not, then the ratio ERC/TNT will be larger, the more complete the TNT detonation.

While the poor detonation of TNT was unexpected, the resultant contaminated soil is representative of that exposed to a variety of functioning and incompletely functioning devices. Therefore, this soil was used to study environmental degradation of TNT and ERC's as might be found at firing ranges and in areas of military activity. Over a period of two months, 5-g samples were removed from the insulated box and analyzed for TNT and other ERC's. The results are illustrated graphically in Figures 2 and 3. The 0,31, and 69 day data are tabulated in Table 9 using an average of three samplings. The degree of variability is represented by the standard deviation. While the TNT content on the Fort Leonard Wood soil appeared homogeneous on day "0", subsequent samples exhibited higher TNT variability. With this exception, the data trend was reasonably consistent. Over the period monitored, we observed a 50\% drop in TNT and 2,4DNT and an increase of up to $100 \%$ in the TNT microbial breakdown products 4-ADNT and 2ADNT (Table 9). With two exceptions, the loss or gain was faster in soils with $10 \%$ moisture content than in those with 5\%. There was no clear trend regarding the change of concentrations depending on soil type (FLW or SNL). For TNT, 2, 4-DNT, and 1,3-DNB rate constants (k) were estimated using the average fraction remaining on the $31^{\text {st }}$ day. Assuming these were first-order rate constants, half-lives $\left(\mathrm{t}_{1 / 2}\right)$ were calculated using the equation:

$$
\mathrm{t}_{1 / 2}=0.693 / \mathrm{k}
$$

Table 9 lists these values. 2, 4-DNT decomposed faster than TNT $\left(2 \times 10^{-7} \mathrm{~s}^{-1}\right.$ compared to $6 \times 10^{-}$ $\left.{ }^{8} \mathrm{~s}^{-1}\right)$. The TNT rate constant is in reasonable agreement with estimates made from preliminary detonations in barrels over sand, where TNT post-blast residue on the sand was quantified at 12 
and 18 months intervals; a rate constant of about $10^{-8} \mathrm{~s}^{-1}$ was found. CRREL estimated half-lives of 2,4-DNT, TNT and 1,3-DNB in Fort Leonard Wood soil at ambient temperature (Table 11). For 2,4-DNT they obtained a half-life of 26 days, while in this study we determined it to be 3149 days $(10 \%, 5 \%$ moisture). This is in reasonable agreement. However, we differ greatly in our estimates of the half-lives of TNT and 1, 3-DNB (Table 11). A significant difference between these studies is that the target compounds were deposited by detonation in our study instead of as aqueous solutions. Deposition by detonation gave no control of the initial concentrations. We believe the initial high concentrations of TNT in this study probably inhibited microbial degradation of TNT. Thus, rather than a half-life on the order of 1 day as observed by CRREL, we see a TNT half-life nearer 100 days (Table 11). This is a matter of great concern when considering the detection of landmines in areas that have already seen military activity.

It was observed that TNT post-blast residue differed from landmine leakage. During the 2.5-year study at a test mine field in Fort Leonard Wood, MO, Jenkins et al (CRREL) found mine leakage produced surface concentrations of TNT in the $1 \mathrm{ppb}$ range in some samples, while others showed no detectable TNT. However, 2,4-DNT and ADNT concentrations were as great or greater than TNT. ${ }^{17}$ It was recommended that detection schemes target 2,4-DNT. In post-blast residue, the amount of TNT can greatly exceed the ERC's (Table 10). Therefore, relatively high 2,4-DNT concentrations accompanied by relatively low TNT concentrations (i.e. a high 2,4DNT/TNT ratio) would be an indication of landmine leakage as opposed to post-blast residue. Data in Table 10 suggests the ERC/TNT ratio may be useful in differentiating the source of residue: 


$\begin{array}{llll} & \begin{array}{l}\text { DNT/TNT } \\ \text { Blast(30\% TNT left) }\end{array} & \begin{array}{l}\text { ADNT/TNT } \\ \sim 10^{-5}\end{array} & \begin{array}{c}\text { DNT/ADNT } \\ \sim 20-60\end{array} \\ \text { Blast }(0.008 \% \text { TNT left })^{16} & \sim 10^{-2} & \sim 10^{-2} & \sim 7-11 \\ \text { Surface mine leakage } & 1-10 \text { 's } & 1-10{ }^{17} & <1\end{array}$

Low concentrations of TNT associated with landmines tend to more rapidly disappear due to bacterial action than the greater concentrations associated with post-blast. Therefore, high DNT/ TNT ratios should be a conclusive identifier of landmine leakage. A further indicator that nitroarenes are from landmines is the ratio 2,4-DNT/ADNT. Generally, post-blast residue yields DNT/ADNT ratios above 10, while the ratio of these species from landmine leakage is generally below 1 (Tables 2 and 10). However, since ADNT's are more difficult to detect than TNT, this observation may not be as useful with the current generation of mine detectors.

\section{Conclusions}

TNT detonation products, other than the target ERC's, were not detected or identified. The GC/ECD system used in this study had high sensitivity but identification is based solely on retention times. The two GC/MS systems in our laboratory had significantly less sensitivity for the targeted ERC's. This restricted our study only to the targeted ERC's which were observed in both postblast samples and pre-blast TNT. Numerous other peaks in the GC/ECD chromatograms could not be identified unless their concentrations were sufficiently high to be detected by GC/MS. In the firing chamber tests, it appeared that the dinitro species $(2,4-\mathrm{DNT}, 1,3-\mathrm{DNB}, 2-\mathrm{ADNT}$, and 4ADNT) survived detonation. Their amount and ratio to TNT were relatively unchanged from preblast to post-blast: DNT/TNT $\sim 10^{-4}$ and ADNT/TNT $\sim 10^{-5}$. We attributed this to a poor 
detonation which left about $30 \%$ of the TNT un-reacted. In an earlier study where only $\sim 4 \%$ of the TNT survived, we found the ERC/TNT ratio an order of magnitude higher. Jenkins also observed large ERC/TNT ratios in the explosion of a PMA2 which left only $0.008 \%$ TNT: DNT/TNT $\sim 10^{-2}$ and ADNT/TNT $\sim 10^{-2}$. These ratios allow clear differentiation of post-blast residue from landmine leakage where the ERC/TNT ratios are greater than one. When the post-blast residue was allowed to equilibrate with moistened soil, the amino-dinitrotoluenes increased, while 2,4-dinitrotoluene, 1,3dinitrobenzene, and TNT decreased. The rate of TNT or 2,4-DNT loss was higher on the soils containing $10 \%$ rather than $5 \%$ moisture, but no clear dependence on soil type was observed. Halflives for the disappearance of 2,4-DNT and TNT were calculated; they were around 40 and 100 days, respectively.

\section{References}

1. Heyman, C. “Trends in Land Mine Warfare” Jane's Information Group, 1995.

2. "Unexploded Ordnance: A Coordinated Approach to Detection and Clearance Is Needed" AO/ NSAAD-95-197, September 1995.

3. Sieber, H.A. "Localization and Identification of Anti-Personal Mines" International Workshop; European Commission, 1995.

\section{MinesFacts V1.2 CD-ROM by U.S. Department of Defense}

5. George, V.; Jenkins, T.F; Phelan, J. M.; Leggett, D.C.; Cragin, J. H.; Webb, S.W.; Oxley, J.C.; Smith, J.L.; Berry, T.E.; Miyares, P.H. "Progress on Determining the Vapor Signature of a Buried Landmine" Proceed. $13^{\text {th }}$ Annual International Symposium on Aerospace/Defense Sensing, Simulation, \& Controls, April 5-9, 1999, Orlando, FL, Vol 3710, pp258-269.

6. George, V.; Jenkins, T.F; Phelan, J. M.; Leggett, D.C.; Cragin, J. H.; Webb, S.W.; Oxley, J.C.; Smith, J.L.; Berry, T.E.; Miyares, P.H. "Progress on Determining the Vapor Signature of a Buried Landmine" Proceed. $14^{\text {th }}$ Annual International Symposium on Aerospace/Defense Sensing, Simulation, \& Controls, April, 2000, Orlando, FL.

7. When this test setup is used to assess explosivity, the cartridge (about $10 \mathrm{~g}$ ) is weighed empty and the cartridge base and any metal remaining attached to it is weighed after the detonation. ${ }^{8-11}$ The 
violence of the event is quantified by the fraction of metal remaining attached to base; the lower the percentage of cartridge remaining, the more powerful the blast.

8. Lidstone, D. P. "The Assessment of Explosive Performance by Means of a Cartridge Case Deformation Test" RARDE Memorandum 15/69.

9. Lowe, A.M "Cartridge Case Test Validation" DRA report, November 1995. Lowe, A.M; Hiley, R. "Cartridge Case Deformation Test;” J. Energetic Materials, 1998, 4.

10. Oxley, J.C.; Smith, J.L.; Rogers, E.; Resende, E.; Mostafa, A. "Small-Scale Explosivity Testing” J. Energetic Materials, 1999, 17(4), 331-343.

11. Oxley, J.C.; Smith, J.L.; Rogers, E.; Resende, E.; "Determining Explosivity Part II: Comparison of Small-Scale Cartridge Test to Actual Pipe Bombs, J. Forensic Science 2001; 46(5): 1070-1075.

12. Zheng, W.; Dong, X.; Rogers, E.; Oxley, J.C.; Smith, J.L.; "Improvements in the Determination of Decomposition Gases from 1,3,3-Trinitroazetidine and 5-Nitro-2,4-dihydro3H-1,2,3-trizol-2-one Using Capillary Gas Chromatography- Mass Spectrometry" J. Chrom. Sci. 1997, 35, 478-482.

13. Jenkins, T.F.; Walsh, M.E.; Schumacher, P.W.; Miyares, P.H. "Liquid Chromatographic Method for Determination of Extractable Nitroaromatic and Nitramine Residues in Soil" $J$. Assoc. Off. Anal. Chem., 1989, 72(6), 890-899. Bauer, C.F.; Koza, S.M.; Jenkins, T.F. "Liquid Chromatographic Method for Determination of Explosives Residues in Soil: Collaborative Study" J. Assoc. Off. Anal. Chem., 1990, 73(4), 541-552.

14. U.S. EPA "Nitroaromatics and Nitramines by HPLC" (Second Update), SW846 Method 8330, 1995. Jenkins, T.F. ; Golden, S.M. "Development of an Improved Confirmation Separation Suitable for use with SW 846 Method 8330” (CRREL Rep. SR 93-14) U.S. Army CRREL, Hanover, NH, 1993.

15. Walsh, M.E.; Jenkins, T.F. "Identification of TNT Transformation Products in Soil” US Army Corps of Engineers, CRREL, 1992, SR-92-16.

16. Jenkins, T.F.; Miyares, P.H.; Collins, N.H.; Hewitt, A.D.; Ranney, T.A. "Use of Surface Snow Sampling to Estimate the Quantity of Explosives Residues Resulting from Landmine Detonations" ERDC Technical Report, 2000.

17. Jenkins, T.F.; Walsh, M.E.; Miyares, P.H.; Kopczynski, J. A.; Ranney, T.A.; George, V.; Pennington, J.C.; Berry, Jr., T.E. "Analysis of Explosive-Related Signature Chemicals in Soil Samples Collected Near Buried Land Mines” ERDC Technical Report, 2000.

18. Jenkins, T.F.; George, V. personal communication. 
Additional information and reprint requests:

Jimmie C. Oxley

Chemistry Department, University of Rhode Island

Kingston, RI 02881

(Phone/fax) (401-874-2103

Email: joxley@chm.uri.edu

\section{List of Figures}

Fig. 1 PMA-2 Anti-Personnel Mine Casing

Fig.2 Changes in TNT \& ERC's Concentrations in Sandia Soil Moistened with 10\% Water

Fig 3 Changes in TNT \& ERC's Concentrations in Fort Leonard Wood Soil Moistened with 5\% Water 
List of Tables

Table 1 Landmine Survey

Table 2 Preliminary CRREL Findings of ERC's at Fort Leonard Wood (ref. 5,6 )

Table 3 Initiator Composition and Explosive Products

Table 4 Experimental Methods: Detection Limits, GC Retention Times

Table 5 TNT Residue from the SSED—Detonations under $\mathrm{N}_{2}$ and under $\mathrm{O}_{2}$

Table 6 TNT and ERC's on Witness Plates in Barrel 1 (analyzed by RTx-225 column)

Table 7 TNT and ERC's on Witness Plates in Barrels Summary of Four Barrels

Table 8 Summary of TNT and ERC's Detected by from Barrel Detonations

Table 9 TNT \& ERC's Post-Blast Aging

Table 10 TNT \& ERC's_-Pre-Blast; Post-Blast; and Landmine Leakage

Table 11 CRREL TNT Aging Studies in Soil 
Table 1. Summary of Available Landmines (from ref. 4)

\begin{tabular}{|c|c|c|c|c|c|c|c|c|c|}
\hline $\begin{array}{ll}\# \text { of } \\
700\end{array}$ & Type & Country & Shape & Explosive & Charge $\mathrm{Kg}$ & Booster & Booster $\mathrm{g}$ & $\begin{array}{l}\text { Charge/ } \\
\text { Booster } \\
\end{array}$ & note \\
\hline 314 MT-4 & $P$ & Yugoslav & Cylinder & TNT & 3.8 & none & 0.00 & & 11 \\
\hline 549 TM-500 & $\mathrm{P}$ & Yugoslav & Brick & TNT & 0.5 & det only & 0.64 & 781 & \\
\hline 429 PMR-3 & $\mathrm{P}$ & Yugoslav & Stake & TNT & 0.4 & det only & 0.64 & 641 & \\
\hline 564 TMA-4 & $\mathrm{T}$ & Yugoslav & Disk & TNT & 5.5 & Tetryl & 10.60 & 519 & \\
\hline 25 AT 11 & $\mathrm{~T}$ & W German & Cylinder & RDX/TNT & 0.9 & Tetryl & 0.00 & 472 & \\
\hline 169 M21 & $\mathrm{T}$ & U.S. & Disk & Comp B & 4.9 & $\mathrm{RDX} / \mathrm{PbN}_{6}$ & 11.20 & 438 & \\
\hline 494 SACIMAC-10 & $\mathrm{T}$ & Italy & & TNT & 10.0 & ---- & 0.03 & 333 & \\
\hline 399 PMA-1 & $P$ & Yugoslav & box & TNT & 0.2 & No 8 det & 0.64 & 313 & 10 \\
\hline 401 PMA-1A & $\mathrm{P}$ & Yugoslav & box & TNT & 0.2 & No 8 det & 0.64 & 313 & 6 \\
\hline 540 TM-200 & $\mathrm{P}$ & Yugoslav & brick & TNT & 0.2 & det only & 0.64 & 313 & \\
\hline 42 B MK 1 & $\mathrm{~T}$ & Egypt & disk & TNT & 7.0 & --- & 0.03 & 233 & \\
\hline $492 \mathrm{SACl} 54 / 7$ & $\mathrm{~T}$ & Italy & disk & TNT & 7.0 & ---- & 0.03 & 233 & \\
\hline 496 SACIMAC-7 & $\mathrm{T}$ & Italy & & TNT & 7.0 & ---- & 30.00 & 233 & \\
\hline 309 MP-APVL F4 & $\mathrm{T}$ & Chile & cylinder & TNT & 2.0 & Pentolite & 10.20 & 196 & \\
\hline 495 SACIMAC-5 & $\mathrm{T}$ & Italy & & TNT & 5.5 & ---- & 0.03 & 183 & \\
\hline 170 M24 & $\mathrm{T}$ & U.S. & rocket & Comp B & 0.9 & Tetryl & 4.86 & 176 & \\
\hline $491 \mathrm{SACl} 54 / 5$ & $\mathrm{~T}$ & Italy & disk & TNT & 5.0 & ---- & 0.03 & 167 & \\
\hline 539 TM-100 & $P$ & Yugoslav & cylinder & TNT & 0.1 & det only & 0.64 & 156 & \\
\hline 298 MODEL 53 & $\mathrm{~T}$ & Swiss & cylinder & TNT & 13.2 & TNT & 0.09 & 153 & \\
\hline 548 TM-46 & $\mathrm{T}$ & Soviet & & TNT, amatol & 5.7 & Tetryl & 37.80 & 151 & \\
\hline 464 PTMI-BAII & $\mathrm{T}$ & Czech & box & TNT & 6.4 & PETN & 50.00 & 129 & \\
\hline 613 Туре 84 & $\mathrm{~T}$ & China & disk & TNT/RDX(50/50) & 5.0 & TNT & 0.04 & 125 & \\
\hline 581 TMSB & $\mathrm{T}$ & Soviet & disk & TNT,amatol & 5.9 & TNT & 50.00 & 118 & 12 \\
\hline 172 M26 & $P$ & U.S. & cylinder & Comp B & 0.2 & Tetryl & 1.50 & 113 & \\
\hline 243 MI AC ID 47 & $\mathrm{~T}$ & French & disk & TNT & 5.4 & PbN6 & 0.05 & 108 & \\
\hline 645 VALMARA 59 & $\mathrm{P}$ & Italy & cylinder & Comp B & 0.5 & TNT & 0.01 & 104 & \\
\hline 566 TMB-1 & $\mathrm{T}$ & Soviet & disk & TNT, amatol & 5.0 & TNT & 50.00 & 100 & 12 \\
\hline 293 MODEL 37 & $\mathrm{~T}$ & Swiss & disk & TNT & 3.0 & TNT & 30.00 & 99 & \\
\hline $168 \mathrm{M} 2$ & $P$ & U.S. & cylinder & TNT & 0.2 & Tetryl & 1.61 & 96 & \\
\hline 173 M34 & $\mathrm{T}$ & U.S. & scatterable & Comp H6 & 1.4 & RDX & 17.40 & 78 & 4 \\
\hline 306 MON-200 & $P$ & Soviet & disk & TNT & 12.0 & TNT & 163.00 & 74 & \\
\hline 547 TM-44 & $\mathrm{T}$ & Soviet & & TNT, amatol & 5.4 & picric acid & 75.00 & 72 & \\
\hline $239 \mathrm{MI}$ AC CP $48 / 55$ & $\mathrm{~T}$ & French & disk & Hexolite & 6.7 & Pentolite & 0.10 & 67 & 5 \\
\hline 383 PDM-1 & W & Soviet & box & TNT & 10.0 & TNT & 150.00 & 67 & \\
\hline 567 TMB-2 & $\mathrm{T}$ & Soviet & disk & TNT, amatol & 5.0 & TNT & 75.00 & 67 & \\
\hline 466 PTMI-BAIII & $\mathrm{T}$ & Czech & disk & TNT & 7.2 & TNT & 115 & 63 & \\
\hline 200 MAT-76 & $\mathrm{T}$ & Romania & disk & TNT & 9.4 & TNT & 0.16 & 58 & \\
\hline 583 TRUPPMINA 10 & $\mathrm{P}$ & Sweden & disk & TNT & 0.1 & Tetryl & 2.00 & 56 & \\
\hline 403 PMA-3 & $P$ & Yugoslav & disk & TNT & 0.0 & det only & 0.64 & 54 & \\
\hline 545 TM-41 & $\mathrm{T}$ & Soviet & cylinder & TNT or amatol & 4.0 & picric acid & 75 & 53 & \\
\hline 470 PTMI-K & $\mathrm{T}$ & Czech & disk & TNT & 4.9 & --- & 99 & 49 & \\
\hline 573 TMD-B & $\mathrm{T}$ & Soviet & box & Amatol, TNT & $9.0,9.7$ & TNT & 0.20 & 49 & \\
\hline 646 VALMARA 69 & $P$ & Italy & cylinder & TNT & 0.6 & RDX & 12.20 & 47 & \\
\hline 398 PM-60 & $\mathrm{T}$ & E. German & disk & TNT & 10.0 & TNT,PETN & 218 & 46 & \\
\hline 554 TM-62M & $\mathrm{T}$ & Soviet & disk & $\begin{array}{c}\text { TNT or TNT/RDX } \\
\text { or TNT/RDX/Al }\end{array}$ & 7.0 & Pentryt & 175 & 40 & 8 \\
\hline 555 TM-62P & $\mathrm{T}$ & Soviet & disk & TNT & $5.7-8.3$ & Pentryt & 175 & 40 & \\
\hline 556 TM-62P3 & $\mathrm{T}$ & Soviet & disk & TNT or TNT/RDX & $6.5-7.5$ & Pentryt & 175 & 40 & \\
\hline 561 TMA-1 & $\mathrm{T}$ & Yugoslav & disk & TNT & 5.6 & TNT/Tetryl & 0.15 & 37 & \\
\hline
\end{tabular}


Table 1. Summary of Available Landmines (from ref. 4) (continued)

\begin{tabular}{|c|c|c|c|c|c|c|c|c|c|}
\hline Name & Type & Country & Shape & Explosive & Charge Kg & Booster & Booster $\mathrm{g}$ & $\begin{array}{l}\text { Charge/ } \\
\text { Booster }\end{array}$ & note \\
\hline 594 Type 59 & $\bar{T}$ & China & disk & $\begin{array}{c}\text { TNT or TGA } \\
60 / 24 / 16\end{array}$ & 6.2 & TNT & 174 & 36 & \\
\hline 551 TM-57 & $\mathrm{T}$ & Soviet & disk & $\begin{array}{c}\text { TNT or TGA } \\
60 / 24 / 16\end{array}$ & 6.0 & TNT & 174 & 35 & \\
\hline 589 Type 51 (wood & & China & box & TNT & 6.8 & TNT & 0.20 & 34 & \\
\hline $240 \mathrm{MI}$ AC CP 48T & $\mathrm{T}$ & French & cylinder & TNT & 7.3 & Pentolite & 0.23 & 32 & \\
\hline 359 OZM-72 & $P$ & Soviet & cylinder & TNT & 0.7 & Tetryl & 23 & 30 & \\
\hline $238 \mathrm{MI}$ AC CP 48 & $\mathrm{~T}$ & French & disk & TNT or picric acid & 6.9 & Pentolite & 0.23 & 30 & \\
\hline 354 NV-41 & $\mathrm{T}$ & Soviet & box & TNT & 5.9 & TNT & 200 & 30 & \\
\hline 463 PTMI-BA & $\mathrm{T}$ & Czech & disk & TNT & 5.9 & TNT & 200 & 30 & \\
\hline 572 TMD-44 & $\mathrm{T}$ & Soviet & box & TNT,ammonite 80 & $4.8-6.7$ & TNT & 200 & 29 & 9 \\
\hline 419 PMN & $P$ & Soviet & disk & TNT & 0.2 & Tetryl & 7 & 29 & \\
\hline 565 TMA-5 & $\mathrm{T}$ & Yugoslav & box & TNT & 5.5 & RDX & 200 & 28 & \\
\hline 215 MC-71 & $\mathrm{T}$ & Romania & 2 cones & TNT & 5.1 & TNT & 225 & 23 & \\
\hline 526 T.MI.35(S) & $\mathrm{T}$ & old German & disk & TNT & 5.3 & Penthrite & 250 & 21 & \\
\hline 37 AUPS & $P$ & Italy & disk & Comp B & 0.1 & $\begin{array}{l}\text { PETN. TNT, or } \\
\text { Tetryl }\end{array}$ & 6 & 18 & 2 \\
\hline 420 PMN-2 & $\mathrm{P}$ & Soviet & disk & TG-40(TNT/RDX) & 0.1 & ---- - & 6 & 18 & \\
\hline 467 PTMI-D & $\mathrm{T}$ & Czech & box & TNT & 6.2 & TNT & 400 & 16 & \\
\hline 529 T/78 & $P$ & Egypt & brick & TNT & 0.2 & RDX & 13 & 15 & \\
\hline 527 T.MI.42 & $\mathrm{T}$ & old German & disk & TNT & 4.7 & PETN & 350 & 13 & \\
\hline 244 MI AC ID 51 & $\mathrm{~T}$ & French & disk & TNT & 6.5 & RDX & 0.50 & 13 & \\
\hline 246 MI AC ID 52 & $\mathrm{~T}$ & French & disk & TNT & 6.5 & RDX & 0.50 & 13 & \\
\hline 693 YAM-5K & $\mathrm{T}$ & Soviet & box & TNT, amatol & 5.0 & TNT & 400 & 13 & \\
\hline 694 YAM-5M & $\mathrm{T}$ & Soviet & box & TNT, amatol & 5.0 & TNT & 400 & 13 & \\
\hline 695 YAM-5U & $\mathrm{T}$ & Soviet & box & TNT, amatol & 5.0 & TNT & 400 & 13 & \\
\hline 299 MODEL 64 & $P$ & Swiss & cylinder & TNT & 0.4 & PETN & 41 & 10 & \\
\hline 294 MODEL 42 & $\mathrm{~T}$ & Swiss & box & TNT & 4.5 & Tetryl & 0.50 & 9 & \\
\hline 163 M16A2 & $P$ & U.S. & cylinder & TNT & 0.5 & Comp A5 & 70 & 7 & 3 \\
\hline 402 PMA-2 & $P$ & Yugoslav & disk & TNT & 0.1 & Hexagen & 15 & 7 & 7 \\
\hline 9 Aluminum & $\mathrm{T}$ & old German & disk & Cheddite & 4.1 & TNT & 600 & 7 & 1 \\
\hline 255 MI AP DV 56 & $\mathrm{P}$ & French & cylinder & TNT & 0.1 & Tetryl & 0.02 & 5 & \\
\hline 256 MI AP DV 59 & $P$ & French & cylinder & TNT & 0.1 & --- & 0.01 & 5 & \\
\hline 153 LMG & $\mathrm{T}$ & Soviet & rocket & TNT & 3.2 & TNT & 780 & 4 & \\
\hline 603 Tyре 72 & $P$ & China & disk & TNT or TNT/RDX $1 / 1$ & 0.1 & RDX/wax & 0.02 & 2 & \\
\hline 608 Type $72 \mathrm{C}$ & $P$ & China & disk & TNT or TNT/RDX $1 / 1$ & 0.0 & RDX/wax & 0.02 & 2 & \\
\hline 528 T.MI.43(P) & $\mathrm{T}$ & old German & disk & TNT & 5.5 & PETN & 3400 & 2 & \\
\hline 607 Tyре 72B & $P$ & China & disk & TNT or TNT/RDX $1 / 1$ & 0.0 & RDX/wax & 24 & 1 & \\
\hline 575 TMM1 & $\mathrm{T}$ & Yugoslav & disk & TNT & 5.6 & & & & \\
\hline 576 TMM1 & $\mathrm{T}$ & Cuba & box wood & TNT & & & & Charge & \\
\hline 587 TS-50 & $\mathrm{P}$ & Italy,Egypt & disk & T4 (like CompB) & & & & Booster & \\
\hline 662 VS 2.2 & $\mathrm{~T}$ & Italy & cylinder & TNT/RDX & 1.9 & & \multirow{2}{*}{\multicolumn{2}{|c|}{ average $=$}} & stdev \\
\hline 664 VS-50 & $P$ & Italy,Egypt & disk & RDX & 0.0 & & & & 147 \\
\hline
\end{tabular}

1 Cheddite $=$ chlorate or perchlorate explosives usually coated with plastic to keep out water

2 Comp B $=$ TNT/RDX 50/50 3 Comp A5 = RDX with stearic acid $(1-1.5 \%$ or $1.6 \%$ \& $0.4 \%$ graphite)

4 Comp H6 = RDX 45\%, TNT 30\%, Al 20\%, D-2 comp 5, CaCl2 0.5\% 5. Hexolite =mixtures of RDX \& TNT

6 Entry 400 PMA-1A is corrupt 7. Hexagen=90\%RDX, $8 \%$ wax \& graphite (in database, but usually just RDX)

8 Pentryt (Pentrit is PETN, possibly the same) 9. $200 \mathrm{~g}$, With Trotyl (TNT) main charge, $160 \mathrm{~g}$

$10 \mathrm{No} 8$ = $11 \mathrm{mg} \mathrm{PbN6}$, 190mg Pb cresol, $450 \mathrm{mg}$ PETN 12 Picture cutout to see inside

11 Cylindrical block of TNT with 2 holes drilled to allow detonating cord for initiation; there is also a fuze well.

Table 2: CRREL Findings of ERC's at Fort Leonard Wood ${ }^{5,6}$ 


\begin{tabular}{|c|c|c|c|c|c|c|}
\hline \multirow{2}{*}{$\begin{array}{c}\text { Depth } \\
\mathrm{cm}\end{array}$} & \multicolumn{5}{|c|}{ Micrograms of ERC from Mine } & \multirow[b]{2}{*}{ 2,6-DNT } \\
\hline & 1,3-DNB & 2,4-DNT & TNT & 4-ADNT & 2-ADNT & \\
\hline \multicolumn{7}{|c|}{ PMA-1A, 200g TNT in box } \\
\hline $0-2.5$ & 34 & 115 & 32 & 566 & 469 & \\
\hline $2.5-5$ & 188 & 87 & 19 & 413 & 431 & \\
\hline $2.5-5$ & & 6 & & 17 & 18 & \\
\hline surface & & 9 & 3 & 38 & 44 & \\
\hline under & 20.9 & 39 & 23 & 81 & 77 & \\
\hline $0-2.5$ & & 16 & 2 & 27 & 8 & \\
\hline surface & & 58 & & 357 & 357 & \\
\hline $0-2.5$ & 20.6 & 93 & 129 & 246 & 209 & \\
\hline $2.5-5$ & & 8 & 17 & 16 & 11 & \\
\hline \multicolumn{7}{|c|}{ TMA-5, 5.5 kg TNT + 200 g RDX booster } \\
\hline $0-5$ & & 6 & 4 & 2 & 8 & \\
\hline $5-10$ & 17.7 & 266 & 27 & 149 & 222 & 3.1 \\
\hline $10-15$ & 79 & 566 & 49 & 316 & 369 & 7 \\
\hline surface & & 6 & 3 & 17 & 17 & \\
\hline $0-5$ & 2.1 & 96 & 28 & 95 & 146 & \\
\hline $5-10$ & 10.4 & 383 & 155 & 300 & 452 & 3 \\
\hline $10-15$ & 146 & 1123 & 1533 & 790 & 806 & 11.7 \\
\hline
\end{tabular}

CRREL $=$ Cold-Region Research \& Engineering Laboratory

Table 3: Initiators for SSED

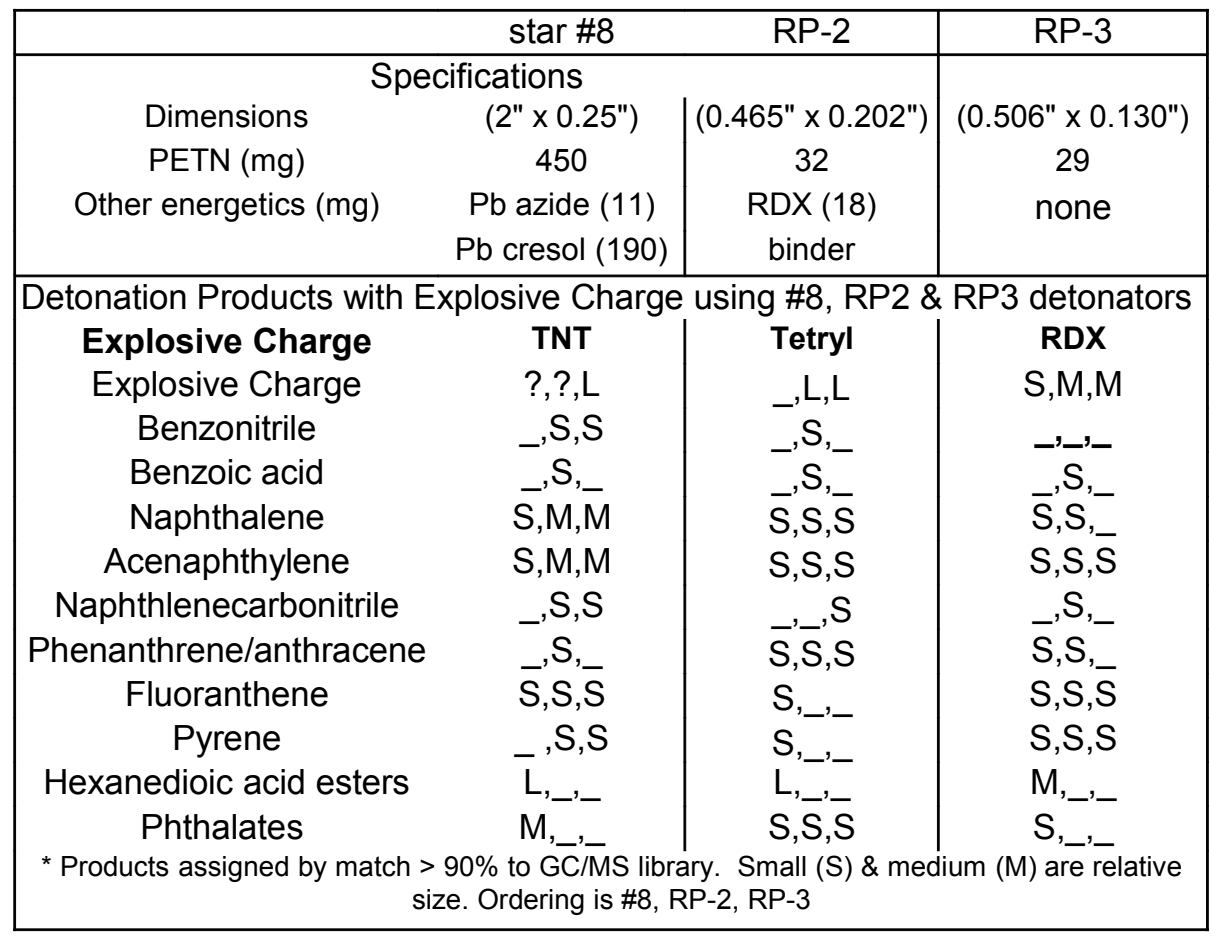

$\mathrm{SSED}=$ Small-Scale Explosivity Device; $\mathrm{S}=$ small; $\mathrm{M}=$ =medium; $\mathrm{L}=$ large 
Table 4:Experimental Methods, Detection Limits, GC Retention Times

\begin{tabular}{|c|c|c|c|c|c|c|c|}
\hline Instrument: & \multirow{2}{*}{\multicolumn{2}{|c|}{$\begin{array}{c}\text { SPME fiber } \\
\text { GC/MS } \\
\text { HP5890/5971 } \\
\text { PoraPLOTQ } \\
25 \times 0.25 \mathrm{~mm} \\
\end{array}$}} & \multicolumn{2}{|c|}{$\begin{array}{c}\text { Plates \& Soil } \\
\text { GC/MS } \\
\text { HP5890/5971 } \\
\end{array}$} & \multicolumn{2}{|c|}{$\begin{array}{c}\text { SSED } \\
\text { GC/ECD } \\
\text { HP } 5890 \\
\end{array}$} & $\begin{array}{c}\text { Plate(TNT \& ERC) \& Soil(ERC) } \\
\text { GC/ECD } \\
\text { HP 5890 }\end{array}$ \\
\hline Column: & & & $\begin{array}{l}\mathrm{J} \& \mathrm{~W} \\
30 \mathrm{~m} x\end{array}$ & $\begin{array}{l}\mathrm{B}-5 \mathrm{MS} \\
0.22 \mathrm{~mm}\end{array}$ & $\begin{array}{l}J \& W \\
30 \mathrm{~m}\end{array}$ & $\begin{array}{r}\text { DB-5MS } \\
\times 0.22 \mathrm{~mm} \\
\end{array}$ & $\begin{array}{|cc|}\mathrm{J} \& W \text { DB-5MS } & \text { RTx-225 } \\
6 \mathrm{~m} \times 0.53 \mathrm{~mm} & 6 \mathrm{~m} \times 0.53 \mathrm{~mm} \\
\end{array}$ \\
\hline Sample in: & SPME fiber & & $\mathrm{CH}_{3} \mathrm{CN}$ o & acetone & & cetone & $\mathrm{CH}_{3} \mathrm{CN}$ \\
\hline $\begin{array}{r}\text { Injector }{ }^{\circ} \mathrm{C} \\
\text { Detector }{ }^{\circ} \mathrm{C} \\
\text { Transfer line }{ }^{\circ} \mathrm{C} \\
\end{array}$ & 100 & & 100 & & $\begin{array}{l}200 \\
300\end{array}$ & $20 \mathrm{~min}$ & $\begin{array}{l}250 \\
300\end{array}$ \\
\hline GC oven & $\begin{array}{l}-805 \min \\
180\end{array}$ & $15^{\circ} \mathrm{C} / \mathrm{min}$ & $\begin{array}{r}75 \\
300\end{array}$ & $\begin{array}{r}20^{\circ} \mathrm{C} / \mathrm{min} \\
20 \mathrm{~min}\end{array}$ & $\begin{array}{r}75 \\
300\end{array}$ & $\begin{array}{rr}5 & 20^{\circ} \mathrm{C} / \mathrm{min} \\
0 & 20 \mathrm{~min}\end{array}$ & $\begin{array}{l}10030 \mathrm{~s}, 2 \mathrm{C} / \mathrm{min} \\
1203 \mathrm{C} / \mathrm{min} \\
13520 \mathrm{C} / \mathrm{min} \\
2803.5 \mathrm{~min}\end{array}$ \\
\hline & $\begin{array}{l}\text { DB-5MS } \\
\text { RT(min.) RRT }\end{array}$ & $\begin{array}{c}\text { MDL ng/ } \\
\mathrm{mL}\end{array}$ & $\begin{array}{l}\text { Restec } \\
\text { RT(min.) }\end{array}$ & RRT & $\begin{array}{l}\mathrm{MDL} \\
\mathrm{ng} / \mathrm{mL}\end{array}$ & $\begin{array}{l}\text { Analysis } \\
\text { Instrument: }\end{array}$ & $\begin{array}{l}\text { TNT } \\
\text { HPLC }\end{array}$ \\
\hline 2,6 DNT & 6.51 & 20 & 6.92 & 1 & 20 & & HP1100 \\
\hline 1,3 DNB & 7.871 .04 & 20 & 7.21 & 1.04 & 20 & Column: & Hypersil BDS-C18 \\
\hline 2,4 DNT & 10.451 .41 & 30 & 7.68 & 1.11 & 35 & & $10 \mathrm{~cm} \times 4 \mathrm{~mm}$ \\
\hline TNT & 10.92 .94 & 10 & 9.8 & 1.42 & 10 & & Photodiode array \\
\hline 4-A-DNT & 19.163 .75 & 15 & 18.8 & 2.72 & 20 & Solvent: & $\mathrm{CH}_{3} \mathrm{CN}$ \\
\hline 2-A-DNT & 19.483 .86 & 15 & 22.04 & 3.18 & 20 & Detector: & $214,235,254 \mathrm{~nm}$ \\
\hline $\mathrm{RT}=$ retention tim & e; RRT=relative ret & ntion time; 1 & $\mathrm{MDL}=$ minim & um detection & n limit & $\begin{array}{l}\text { Solvents: } \\
\text { Flow rate: } \\
\text { Methanol } \\
\text { Gradient: }\end{array}$ & $\begin{array}{l}\text { H2O/methanol } \\
0.72 \mathrm{~mL} / \mathrm{min} \\
26 \% \\
40 \%, 55 \%, 70 \% \\
\end{array}$ \\
\hline
\end{tabular}

Table 5: Detonation of TNT in Nitrogen vs. Oxygen in SSED

\begin{tabular}{|c|c|c|c|c|c|c|c|c|c|}
\hline & Sample & TNT (q) & Initiator & Cartridg & ght (q) & Fraction & Cartridge & TNT & \% TNT \\
\hline & $\begin{array}{l}2 \mathrm{~g} \text { TNT } \\
\text { flake }\end{array}$ & & & Start & End & Remaining & Shattered & & \\
\hline 122 & Sample $1 \mathrm{~N}_{2}$ & 2.0011 & RP-3 & 10.944 & 9.708 & 0.887 & 0.113 & 0.503 & $25 \%$ \\
\hline 123 & Sample $2 \mathrm{~N}_{2}$ & 2.0002 & RP-3 & 11.051 & 9.854 & 0.892 & 0.108 & 0.954 & $48 \%$ \\
\hline 124 & Sample $3 \mathrm{O}_{2}$ & 2.0044 & RP-3 & 10.993 & 10.874 & 0.989 & 0.011 & 0.034 & $2 \%$ \\
\hline 125 & $\begin{array}{c}\text { Sample } 4 \mathrm{O}_{2} \\
2 \mathrm{~g} \text { TNT } \\
\text { powder }\end{array}$ & 2.0066 & RP-3 & 10.922 & 9.703 & 0.888 & 0.112 & 0.046 & $2 \%$ \\
\hline & 7 TNT in air & 2.0001 & \#8 & 11.030 & 3.305 & 0.300 & 0.700 & & \\
\hline & 8 TNT in air & 2.0000 & RP-2 & 10.997 & 3.334 & 0.303 & 0.697 & & \\
\hline & 9 TNT in air & 2.0002 & RP-3 & 10.996 & 3.976 & 0.362 & 0.638 & & \\
\hline & 8 TNT in air & 2.0002 & RP-3 & 10.980 & 4.154 & 0.378 & 0.622 & & \\
\hline
\end{tabular}


Table 6: Witness Plate ERC's from 75g TNT in 55 Gallon Barrel

\begin{tabular}{|c|c|c|c|c|c|c|c|c|c|c|c|c|c|c|}
\hline \multirow{3}{*}{$\begin{array}{l}\text { Barrel \# } \\
\text { Barrel } 1\end{array}$} & \multirow{3}{*}{$\begin{array}{r}\text { Row } \\
\text { R1 }\end{array}$} & \multicolumn{13}{|c|}{ Micrograms (ug) sample on each plate as analyzed on RTX-225 GC column } \\
\hline & & \multirow{2}{*}{$\begin{array}{r}\text { Plate } \\
1\end{array}$} & \multirow{2}{*}{$\begin{array}{l}\text { TNT } \\
28947\end{array}$} & \multirow{2}{*}{ st dev } & \multicolumn{2}{|c|}{1,3 DNB st dev } & \multicolumn{2}{|c|}{ 2,6 DNT st dev } & \multicolumn{2}{|c|}{2,4 DNT st dev } & \multicolumn{4}{|c|}{ 2-ADNT st dev 4-ADNT st dev } \\
\hline & & & & & 4.24 & & 3.02 & & 22.53 & & NA & & NA & \\
\hline & & 2 & 25359 & & 1.82 & & 1.66 & & 13.94 & & NA & & NA & \\
\hline & & 3 & 16121 & & 3.68 & & 6.18 & & 23.43 & & NA & & NA & \\
\hline & & 4 & 9350 & & 0.96 & & 1.03 & & 5.66 & & 1.13 & & 1.83 & \\
\hline & & 194 & 10613 & & 0.92 & & 1.36 & & 6.94 & & 1.15 & & 1.76 & \\
\hline & & 6 & 14596 & & 3.39 & & 4.42 & & 18.38 & & 2.44 & & 4.31 & \\
\hline & & 7 & 12611 & & 1.96 & & 2.22 & & 13.92 & & 1.51 & & 2.35 & \\
\hline & & 8 & 10677 & & 1.11 & & 1.46 & & 7.95 & & 1.63 & & 2.55 & \\
\hline & & Average & 16034 & 7273 & 2.26 & 1.32 & 2.67 & 1.80 & 14.09 & 6.94 & 1.57 & 0.53 & 2.56 & 1.03 \\
\hline & R2 & 9 & 3785 & & 3.48 & & 3.54 & & 23.46 & & NA & & NA & \\
\hline & & 10 & 33144 & & 3.28 & & 3.19 & & 18.62 & & NA & & NA & \\
\hline & & 11 & 41614 & & 9.89 & & 6.90 & & 28.08 & & NA & & NA & \\
\hline & & 12 & 16630 & & 4.76 & & 4.73 & & 18.74 & & 2.01 & & 2.65 & \\
\hline & & 13 & 18744 & & 14.94 & & 13.34 & & 24.35 & & 3.17 & & 4.19 & \\
\hline & & 14 & 18610 & & 7.32 & & 7.34 & & 26.28 & & 3.88 & & 5.02 & \\
\hline & & 15 & 17659 & & 5.56 & & 7.26 & & 24.83 & & 2.93 & & 3.97 & \\
\hline & & 16 & 18661 & & 5.52 & & 6.73 & & 24.97 & & 3.69 & & 5.04 & \\
\hline & & Average & 21106 & 11434 & 6.84 & 3.91 & 6.63 & 3.18 & 23.66 & 3.37 & 3.14 & 0.74 & 4.17 & 0.98 \\
\hline & R3 & 17 & 12230 & & 0.74 & & 2.10 & & 6.19 & & NA & & NA & \\
\hline & & 18 & 11256 & & 1.00 & & 0.85 & & 4.82 & & NA & & NA & \\
\hline & & 19 & 27904 & & 1.76 & & 2.12 & & 16.78 & & NA & & NA & \\
\hline & & 20 & 18074 & & 5.21 & & 9.30 & & 26.23 & & 3.90 & & 2.85 & \\
\hline & & 21 & 15148 & & 1.76 & & 3.66 & & 21.40 & & 4.89 & & 7.63 & \\
\hline & & 22 & 10616 & & 0.45 & & 1.14 & & 5.67 & & 1.79 & & 3.34 & \\
\hline & & 23 & 13079 & & 0.85 & & 1.18 & & 6.86 & & 2.02 & & 4.33 & \\
\hline & & 24 & 10807 & & 0.38 & & 0.69 & & 3.15 & & 0.90 & & 1.81 & \\
\hline & & Average & 14889 & 7 5832 & 1.52 & 1.58 & 2.63 & 2.86 & 11.39 & 8.79 & 2.70 & 1.64 & 3.99 & 2.23 \\
\hline & Top & 29 & 29295 & & 5.13 & & 1.85 & & 13.82 & & NA & & NA & \\
\hline & & 30 & & & his plate & was & not reco & verec & after the & detc & nation & & & \\
\hline & & 31 & 10437 & & 10.19 & & 0.80 & & 6.71 & & NA & & NA & \\
\hline & & 32 & 64186 & & 0.47 & & 0.44 & & 1.77 & & NA & & NA & \\
\hline & & Average & 34639 & 27270 & 5.26 & 4.86 & 1.03 & 0.73 & 7.44 & 6.06 & & & 3.37 & 0.97 \\
\hline & Bot & 25 & 23257 & & 0.94 & & 1.24 & & 8.47 & & NA & & NA & \\
\hline & & 26 & 13694 & & 1.19 & & 2.18 & & 15.49 & & 2.42 & & 2.92 & \\
\hline & & 27 & 33543 & & 6.46 & & 5.13 & & 25.98 & & NA & & NA & \\
\hline & & 28 & 36290 & & 10.97 & & 5.33 & & 25.37 & & NA & & NA & \\
\hline RTX-225 & & Average & 26696 & 10325 & 4.89 & 4.78 & 3.47 & 2.07 & 18.83 & 8.42 & & & 3.14 & 0.22 \\
\hline Sum $\mathrm{E}$ & & & 626937 & & 120 & & 112 & & 491 & & 39 & & 57 & \\
\hline
\end{tabular}


Table 7: Summary TNT \& ERC's on Plates in Barrels

\begin{tabular}{|c|c|c|c|c|c|c|c|c|c|c|c|}
\hline & Detonated & & & Total Micr & grams of & ERC fou & nd on Pla & tes in $\mathrm{e}$ & ch Barr & & \\
\hline Barrel & gram TNT & \# Plates & \% Barrel(1) & TNT (ug) & \% TNT (2) & ug/ plate & 1,3 DNB & 2,6 DNT & 2,4DNT & 2-ADNT & DNT \\
\hline 1 & 76.9 & 31 & $15.1 \%$ & 626937 & $5.40 \%$ & 20224 & 120 & 112 & 491 & 59 & 109 \\
\hline 2 & 75.6 & 31 & $15.1 \%$ & 487730 & $4.28 \%$ & 15733 & 104 & 75 & 395 & 70 & 124 \\
\hline 3 & 76.2 & 32 & $15.6 \%$ & 451625 & $3.80 \%$ & 14113 & 157 & 113 & 544 & 41 & 49 \\
\hline 4 & 74.3 & 13 & $6.3 \%$ & 207686 & $4.42 \%$ & 15976 & 52 & 46 & 191 & 20 & 27 \\
\hline & & Average & $\begin{array}{l}\mathrm{RTx}-225 \\
\text { total TNT (g) }\end{array}$ & $\begin{array}{r}522097 \\
3.35\end{array}$ & $\begin{array}{l}4.48 \% \\
4.46 \%\end{array}$ & $\begin{array}{r}16512 \\
\% \text { out of }\end{array}$ & $75 \mathrm{~g}$ TNT & & & & \\
\hline 1 & 76.9 & 31 & $15.1 \%$ & 481955 & $4.15 \%$ & 15547 & 159 & 94 & 580 & 82 & 76 \\
\hline 2 & 75.6 & 31 & $15.1 \%$ & 464829 & $4.08 \%$ & 14994 & 143 & 66 & 395 & 93 & 76 \\
\hline 3 & 76.2 & 32 & $15.6 \%$ & 493825 & $4.16 \%$ & 15432 & 133 & 8 & 525 & 97 & 74 \\
\hline 4 & 74.3 & 13 & $6.3 \%$ & 158771 & $3.38 \%$ & 12213 & 55 & 9 & 162 & 23 & 31 \\
\hline & & Average & DB-5MS & 480203 & $3.94 \%$ & 14547 & & & & & \\
\hline & & (3) & total TNT (g) & 3.08 & $4.10 \%$ & $\%$ out of & g TNT & & & & \\
\hline
\end{tabular}

(1) $\left[\left(4^{\prime \prime *} 4 "\right)^{\star} \#\right.$ plates\}/3288 in ${ }^{2} \quad$ (3) Average ug TNT/(0.156*e6)

(2) ugTNT $^{\star}(75000000 * \%$ of 3288 sq.in. barrel) where detonation was with $75 \mathrm{~g}$ TNT

Table 8: Micrograms of TNT Detected after Blast \& Percentage of ERC based on TNT

\begin{tabular}{|c|c|c|c|c|c|c|c|c|c|}
\hline column & ERC/TNT & mg TNT & $1,3 \mathrm{DNB}$ & & 2,6 DNT & ug & 2,4 DNT & ug 2-ADNT & ug 4-ADNT \\
\hline RTX-225 & plate ${ }^{*}$ & 16.5 & $\begin{array}{ll}4.0 & 0.024 \% \\
\end{array}$ & 3.2 & $0.020 \%$ & 15.2 & $0.092 \%$ & $1.5 \quad 0.009 \%$ & $2.20 .014 \%$ \\
\hline DB-5MS & plate & 14.6 & $4.6 \quad 0.031 \%$ & 1.7 & $0.011 \%$ & 15.5 & $0.106 \%$ & $2.80 .019 \%$ & $2.40 .017 \%$ \\
\hline DB-5MS & SPME & 0.02 & $4.6 \mathrm{E}-04 \quad 0.002 \%$ & $2.6 \mathrm{E}-04$ & $0.001 \%$ & $1.0 \mathrm{E}-03$ & $0.005 \%$ & not de & ermined \\
\hline
\end{tabular}

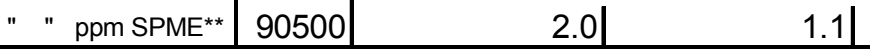

* Values from average residue in each row and multiplying by the number of plates in row and summing over the barrel.

** Ave. ERC's (ug)--5 SPME fibers was divided by barrel volume (231L) to estimate $\mathrm{mg} \mathrm{ERC/cm3} \mathrm{of} \mathrm{air} \sim \mathrm{ppm}$.

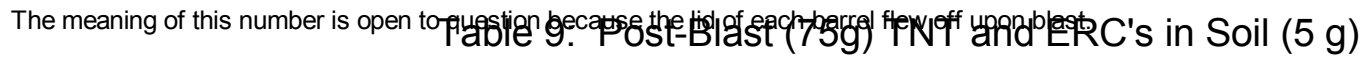
day 0 after 31 days at ambient after 63-69 days at ambient

\begin{tabular}{|c|c|c|c|c|c|c|c|c|c|c|c|c|c|c|}
\hline & & & & art & & days & Fraction & rate constant & half-life & SNL 69d/ & W 63d & Fraction & rate constant & half-life \\
\hline ERC & Soil & water & $\mathrm{mg}$ & std dev & $\mathrm{mg}$ & std dev & Lost & $1 / \mathrm{sec}$ & days & mg & std dev & Lost & $1 / \mathrm{sec}$ & days \\
\hline TNT & Ft L.W. & $10 \%$ & 77 & 4 & 64 & 24 & 0.17 & $6.8 \mathrm{E}-08$ & 118 & 37 & 13 & 0.52 & $1.3 \mathrm{E}-07$ & 60 \\
\hline & & $5 \%$ & 77 & 4 & 55 & 9 & 0.29 & $1.3 \mathrm{E}-07$ & 63 & 41 & 4 & 0.47 & $1.2 \mathrm{E}-07$ & 69 \\
\hline & Sandia NL & $10 \%$ & 84 & 7 & 69 & 1 & 0.18 & 7.4E-08 & 109 & 57 & 3 & 0.32 & $6.4 \mathrm{E}-08$ & 126 \\
\hline & & $5 \%$ & 84 & 7 & 73 & 2 & 0.13 & $5.1 \mathrm{E}-08$ & 157 & 61 & 6 & 0.27 & $5.4 \mathrm{E}-08$ & 149 \\
\hline & & & ug & & ug & & avg. & $8.0 \mathrm{E}-08$ & & ug & & avg. & $9.2 \mathrm{E}-08$ & \\
\hline 2,4-DNT & Ft L.W. & $10 \%$ & 43 & 3 & 22 & 1 & 0.50 & 2.6E-07 & 31 & 18 & 4 & 0.58 & $1.6 \mathrm{E}-07$ & 50 \\
\hline & & $5 \%$ & 43 & 3 & 28 & 4 & 0.36 & 1.6E-07 & 49 & 19 & 2 & 0.56 & 1.5E-07 & 53 \\
\hline & Sandia N L & $10 \%$ & 52 & 4 & 25 & 0.1 & 0.52 & 2.7E-07 & 30 & 21 & 1 & 0.60 & $1.5 \mathrm{E}-07$ & 53 \\
\hline & & $5 \%$ & 52 & 4 & 27 & 0.9 & 0.48 & $2.4 \mathrm{E}-07$ & 33 & 20 & 1 & 0.61 & $1.6 \mathrm{E}-07$ & 51 \\
\hline & & & & & & & avg. & 2.3E-07 & & & & avg. & $1.6 \mathrm{E}-07$ & \\
\hline 1,3-DNB & Ft L.W. & $10 \%$ & 4.6 & 0.3 & 4.1 & 1 & 0.11 & 4.5E-08 & 178 & 3.8 & 1 & 0.18 & 3.7E-08 & \\
\hline & & $5 \%$ & 4.6 & 0.3 & 3.7 & 0.3 & 0.20 & $8.2 \mathrm{E}-08$ & 98 & 4.8 & 0.0 & -- & -- & \\
\hline & Sandia N L & $10 \%$ & 6.2 & 0.4 & 4.5 & 0.1 & 0.28 & $1.2 \mathrm{E}-07$ & 66 & 5.8 & 0.4 & 0.06 & $1.0 \mathrm{E}-08$ & \\
\hline & & $5 \%$ & 6.2 & 0.4 & 5.0 & 0.2 & 0.20 & $8.1 \mathrm{E}-08$ & 99 & 5.6 & 0.3 & 0.10 & 1.7E-08 & \\
\hline & & & & & & & Gained & & & & & Gained & & \\
\hline 2-ADNT & Ft L.W. & $10 \%$ & 1.4 & 0.1 & 3.0 & 0.3 & 1.17 & $2.9 \mathrm{E}-07$ & 28 & 2.2 & 0.0 & 0.54 & $-8.0 \mathrm{E}-08$ & \\
\hline & & $5 \%$ & 1.4 & 0.1 & 2.5 & 0.4 & 0.76 & 2.1E-07 & 38 & 1.8 & 0.3 & 0.26 & $-4.3 E-08$ & \\
\hline & Sandia N L & $10 \%$ & 1.4 & 0.2 & 3.0 & 0.06 & 1.16 & $2.9 \mathrm{E}-07$ & 28 & 2.5 & 0.2 & 0.77 & $-9.6 \mathrm{E}-08$ & \\
\hline & & $5 \%$ & 1.4 & 0.2 & 2.7 & 0.1 & 0.91 & 2.4E-07 & 33 & 1.6 & 0.2 & 0.17 & $-2.7 \mathrm{E}-08$ & \\
\hline 4-ADNT & Ft L.W. & $10 \%$ & 0.7 & 0.07 & 1.6 & 0.05 & 1.30 & 3.1E-07 & 26 & 1.5 & 0.1 & 1.16 & $-1.4 \mathrm{E}-07$ & \\
\hline & & $5 \%$ & 0.7 & 0.07 & 1.2 & 0.1 & 0.75 & 2.1E-07 & 39 & 0.9 & 0.1 & 0.29 & $-4.6 \mathrm{E}-08$ & \\
\hline & Sandia N L & $10 \%$ & 0.8 & 0.17 & 1.3 & 0.1 & 0.67 & $1.9 \mathrm{E}-07$ & 42 & 0.9 & 0.1 & 0.15 & $-2.3 \mathrm{E}-08$ & \\
\hline & & $5 \%$ & 0.8 & 0.17 & 1.1 & 0.09 & 0.44 & 1.4E-07 & 58 & 0.7 & 0.1 & -- & -- & \\
\hline
\end{tabular}


Table 10: TNT and ERC's Available: a Comparison of Post-Blast \& Mine Leakage

\begin{tabular}{|c|c|c|c|c|c|c|c|c|c|}
\hline \multirow[t]{2}{*}{ Source of Species } & ug/g soil & \multicolumn{4}{|c|}{ ERC's Detected as \% of TNT } & \multirow[b]{2}{*}{ 4ADNT } & \multirow{2}{*}{$\begin{array}{c}\# \\
\text { runs }\end{array}$} & \multicolumn{2}{|c|}{ 2,4DNT/ADNT } \\
\hline & TNT & 1,3 DNB & 2,6 DNT & 2,4 DNT & 2ADNT & & & 2ADNT & 4ADNT \\
\hline TNT as received $\%$ & 0 & $0.004 \%$ & & $0.017 \%$ & $0.001 \%$ & $0.000 \%$ & 2 & 17 & 44 \\
\hline Post-Blast & $\sim 30 \%$ & & & & & & & & \\
\hline Soil, Chamber, 0 day & 16187 & $0.007 \%$ & & $0.059 \%$ & $0.002 \%$ & $0.001 \%$ & 10 & 37 & 73 \\
\hline Soil, Chamber, 31 days & 13337 & $0.007 \%$ & & $0.039 \%$ & $0.004 \%$ & $0.002 \%$ & 6 & 9 & 20 \\
\hline Soil, Chamber, 63-69 d & 9836 & $0.011 \%$ & & $0.041 \%$ & $0.004 \%$ & $0.002 \%$ & & 10 & 22 \\
\hline Witness plates, Barrel & $4 \%$ & $0.028 \%$ & $0.015 \%$ & $0.100 \%$ & $0.014 \%$ & $0.015 \%$ & 107 & 8 & 7 \\
\hline PMA2 (100g TNT), snow ${ }^{16}$ & 0.008 & ND & ND & $3.3 \%$ & $1.2 \%$ & $1.7 \%$ & 14 & & \\
\hline Landmine Leakage & $\mathrm{ug} / \mathrm{g}$ & & & & & & & & \\
\hline average above TMA $5^{18}$ & 0.257 & $32 \%$ & $2 \%$ & $80 \%$ & $77 \%$ & $71 \%$ & 44 & 0.83 & 0.88 \\
\hline TMA5-mean surface ${ }^{17}$ & 0.0042 & & & $369 \%$ & $405 \%$ & $398 \%$ & & 0.91 & 0.93 \\
\hline PMA1A-mean surface ${ }^{17}$ & 0.0038 & & & $832 \%$ & $1147 \%$ & $1166 \%$ & & 0.72 & 0.71 \\
\hline ug/g soil max & 0.023 & & & & & & & & \\
\hline
\end{tabular}

Table 11: Half-life estimates measured at $\mathrm{CRREL}^{16,17}$

\begin{tabular}{|c|c|c|c|}
\hline \multicolumn{3}{|c|}{ Half Life in Days Determined at $22^{\circ} \mathrm{C}$} & TNT \\
\hline Fort Leonard Wood & 25.7 & 9.9 & 1.3 \\
\hline Windsor Sandy Loam & 49.5 & & 1.9 \\
\hline Charlton Silty Loam & 53.3 & & $3.5,2.4$ \\
\hline Fort Edwards Clay & 1.5 & & $<1$ \\
\hline \multicolumn{4}{|c|}{ Half Life in Days Determined $-4^{\circ} \mathrm{C}$} \\
\hline Fort Leonard Wood & 86 & 84 & 80 \\
\hline Windsor Sandy Loam & 178 & & 16.5 \\
\hline Charlton Silty Loam & 233 & & 19.8 \\
\hline Fort Edwards Clay & 13.3 & & 1.4 \\
\hline
\end{tabular}




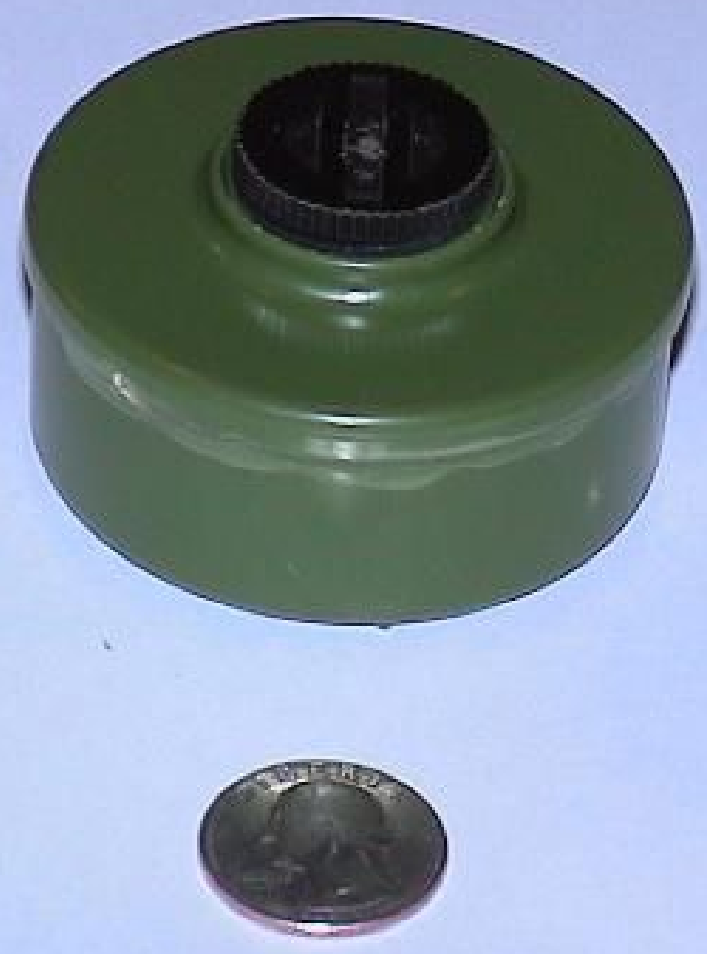

Figure 1 PMA-2 Anti-Personnel Mine Casing (size compared to quarter) 


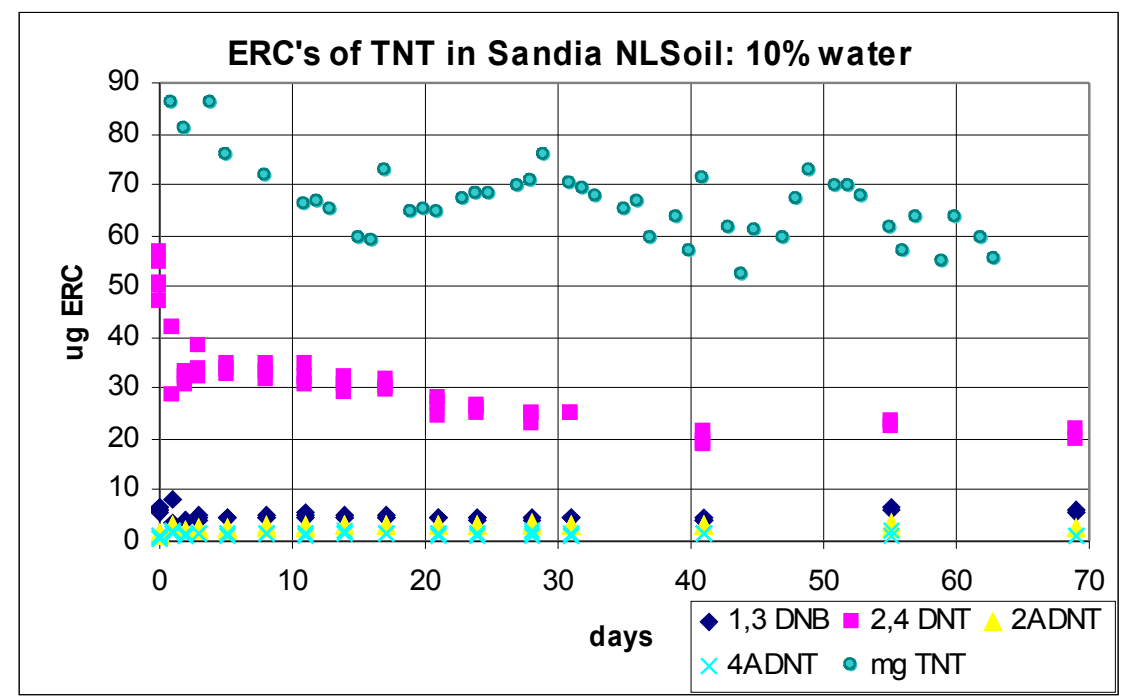

Figure 2 Changes in TNT \& ERC's Concentrations in Sandia Soil Moistened with 10\% Water

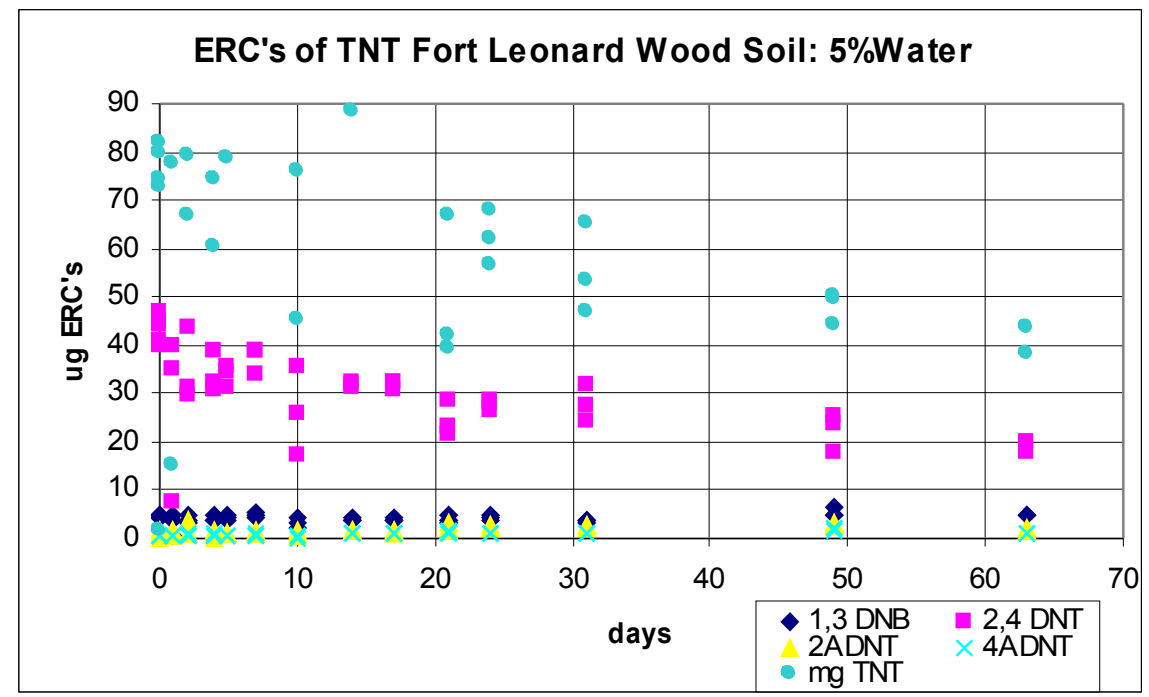

Figure 3 Changes in TNT \& ERC's Concentrations in Fort Leonard Wood Soil Moistened with 5\% Water 